\title{
Inquiry-based E-LKPD in effort to improve the fourth grade students' learning outcome
}

\author{
Samsi Nur Hidayati ${ }^{1^{*}}$ \\ Sunyono ${ }^{2}$ \\ Lilik Sabdaningtyas ${ }^{3}$ \\ ${ }^{1,2,3}$ Postgraduate Program, University of Lampung, Bandar Lampung, Indonesia
}

\begin{abstract}
This study aims to determine 1) the feasibility of inquiry-based e-LKPD, 2) the importance of eLKPD in the process of learning mathematics in elementary schools, 3) the improvement of students' mathematics learning outcome. The syntax of inquiry-based e-LKPD is student orientation to problems, organizing students to learn, guiding the investigation of individual and group participants, developing and presenting work results, analyzing and evaluating problemsolving processes. The data were collected through interviews, questionnaires, and tests. The results showed that the low thematic learning outcomes of students was due to the fact that educators had not fully used teaching materials and models that could improve learning outcomes, so it was hoped that the inquiry-based e-LKPD could improve the fourth grade students' thematic learning. It is clear that inquiry is one of the learning strategies that can be applied as a solution in improving student learning outcomes, in accordance with the characteristics of the students. Therefore, it can be concluded that the inquiry-based e-LKPD to improve student learning outcomes in elementary schools needs to be developed.
\end{abstract}

\section{KEYWORDS}

e-LKPD, inquiry, learning outcome

Received: 2 August 2021

Accepted: 15 August 2021

Published: 20 August 2021

\section{Introduction}

The Covid-19 pandemic has also had a severe impact on education, including elementary school education. The Minister of Education and Culture (2020) issued a Circular Letter No. 4 of 2020 concerning the implementation of education policies in the emergency period of the corona virus disease (covid-19) decided to implement online learning in Indonesia, which means need internet access. Carl J. Wenning in his research entitled Levels of Inquiry Hierarchies of Pedagogical Practices and Inquiry Processes explained that there are eight kinds of stages in inquiry, namely 1) discovery learning, 2) interactive demonstration, 3) inquiry lesson, 4) guided inquiry lab, 5) bounded inquiry lab, 6) free inquiry lab, 7) pure hypothetical inquiry, and 8) applied hypothetical inquiry (Wenning, 2005). Meanwhile, according to (Hairida, 2016) students are able to naturally understand nature in their surrounding and are able to acquire inquiry skills. The implementation of online learning is determined by several supporting factors including mobile phones, internet quotas and networks as well as the availability of appropriate teaching materials (Putria et al., 2020). Media is any tool that can be utilized in delivering messages to achieve learning objective (Djamarah, 2002). The Ministry of National Education (2004) defines LKPD as multiple sheets containing tasks that must be done by students, usually in the form of instructions or steps and has a clear basic competency that need to be achieved.

Arief (2015) stated that "LKPD is one of the tools to help and facilitate learning activities to obtain effective interactions between students and teachers, and able to rise student activities in improving learning achievement". In facilitating students to develop knowledge, it is necessary to use learning tools that is able to emphasize the 'process' including applying the inquiry learning model (Mulia, et al., 2019).

Murhamah, et al., (2017) revealed that the ability to increase student learning outcomes can be attempted through inquiry activities, as in the implementation students are trained to conclude valid research results based on evidence which obtained through experiments. (Yustini, et al., 2018) mentioned that the inquiry learning model requires students to more actively build their own concepts in order to solve problems with investigative activities. (Ramlawati et al., 2014) stated that an interactive design of LKPD is electronic LKPD, which provide worksheets in digital version and carried out systematically and continuously over a certain period of time.

In the Sigil application, the E-LKPD is able to be added with images, animations, songs, and learning support 
videos that can be used by students (Putry, 2018). Khan, et al., (2017) stated that the availability of access to learning anytime and anywhere provides benefits and increases accessibility. Most students possess mobile devices and access to learning might increase the chances of success.

The application of E-LKPD in learning has an impact on students' learning activities which is fun, interactive, provides opportunities for students to practice and motivates students in learning. According to (Trianto, 2013) the Electronic Student Worksheet (E-LKPD) is a series of activities used by students in conducting investigations and problem solving. (Muzenda, 2013) During learning, teacher is still needed in interacting with students as a facilitator and evaluator of students' understanding, therefore the role of teacher remains influential in learning outcomes.

Thematic learning is an effort to integrate knowledge, skills, values or learning attitudes, as well as creative thinking based on themes (Sutirjo as cited in Suryosubroto, 2009). This learning model expects students to understand the real problem and to create a model based on reality that requires a set of competencies. This competency includes the ability to recognize the quantity referred to or included in a situation and to search for available information and to review between relevant and irrelevant information (Maass, 2006), which is clearly a characteristic of information literacy.

Polya stated in (Orton, 2004) Students understand the problem; 2) Students able to arrange plans to solve problems; 3) Students use plans in problem solving; and 4) Students re-evaluate the results of problem solving that has been done. (Turmudi, 2010) stated that the best effort of a teacher in learning mathematics is to stimulate students ability in searching independently, using reasoning in conducting investigations in order to prove a problem.

From the results of initial observations, it was found that educators had not used learning media yet, especially during this pandemic. Thus, the learning process becomes boring and less interesting for students. Students were less enthusiastic in learning because they were not actively involved in learning process. Based on this situation, teachers need to develop methods that can actively involve students in learning process, where students can find their own data, facts and information from the learning activities. Based on these demands, the authors decided to use the inquiry method in this research.

The inquiry method is a method that provides opportunities for students to be actively involved in the learning process and able to stimulate students to think and find their own answers to the given questions as well as questions that arise from students. The purpose of improving learning that expected to be achieved in this study is to improve the learning outcomes of fourth grade students in elementary schools in a cluster of Sidowaluyo subdistrict.

\section{Research method}

This study used a descriptive qualitative study analysis based on literature review, in order to improve student learning outcomes and achieve learning objectives optimally. Literature review as a method to understood comprehensively the related topic by Cooper (as cited in Perignat, 2018). The population in this study were educators and fourth grade students of one cluster elementary school in Sidomulyo sub-district who had implemented the 2013 curriculum. The initial data were collected through questionnaires, interviews, tests and documentation. The sample in this study were 25 students in fourth grade of SDN 02 Sidowaluyo, South Lampung. Data collection techniques using instruments or questionnaire sheets as follows:

Table 1. Questionnaire sheet indicators

\begin{tabular}{ll}
\hline Aspects & Indicators \\
\hline e-LKPD & Application of $e$-LKPD \\
\cline { 2 - 2 } Ease of learning \\
& Presentation of questions \\
\hline The attractiveness of e-LKPD \\
\hline Assist learning process \\
\hline Develop scientific attitude \\
\hline The ability to motivate \\
\hline Difficulty in understanding e-LKPD \\
\hline Material presentation \\
\hline Agree with the development of inquiry-based \\
$e$-LKPD
\end{tabular}

In analyzing the data, researcher used the model of Miles and Hubermen (1990). The model consists of several stages starting with collecting data, reducing, displaying data and verifying or drawing final conclusions. This activity was developed by researchers by referring to the opinion of Mukhtar (2013) with the model of Miles and Huberman (1990).

In this analysis activity, researcher performed the stages of data analysis as follows: (1) Data collection. Researcher collected all data resulted from observations and interviews, which are called raw data; (2) Data reduction. 
After collecting data, the researcher selected, simplified, concentrated, and categorized the data that had been obtained in the field. Then, the researcher abstracted or draw a summary of the data; (3). Data display, compiled information and checked the validity of data in an effort to draw conclusions; (4). Data verification, conclusion drawing, analysis, and decision how to learn using inquiry-based e-LKPD; (5) Research report.

\section{Results and discussion}

Based on the results of interviews and questionnaires in google forms, it shows that there were educators who had not used LKPD as teaching materials in the learning process. Whereas LKPD is a sheet that can be used by educators to convey information better, interesting and enable students to be more active. LKPD could be utilized as an evaluation tool, according to its function.

Based on the development in the 21st century which prioritizes technological aspects in learning, the LKPD can be applied electronically to support an effective and efficient learning. This is reinforced by the results of research (Zahara, 2021), indicate that it was necessary to develop electronic worksheets that were integrated with STEM to facilitate the learning process, especially on materials that are difficult to understand. The development of e-LKPD can be used as a solution to achieve 21 st century skills. In this modern era, an electronic learning is a mandatory tool that must be developed. This is known as e-LKPD (Subakti, 2021). e-LKPD as one of the teaching materials is needed by students to participate actively and creatively during classroom learning (Suparman, 2019). In order to use teaching materials in the form of e-LKPD, a learning strategy is needed to support the learning process in the form of an inquiry model. The purpose of cognitive teaching is to prepare students in transferring process. "Being able to think" means that students able to apply the knowledge and skills that they have developed during learning into new contexts (applications that had not been thought by students previously, not necessarily something universally new.

Thus, an effective learning model is needed to improve student learning outcomes, namely inquiry. This is reinforced by the results of this study, Sanjaya (2006) which stated that the inquiry learning model is a series of learning activities that emphasize the thinking process to search and find the answer of a problem that occurred in question. In addition, the results of this study are also supported by several studies including research conducted by Kritianto (2019), the results show that he application of the inquiry learning model was able to improve critical thinking and student learning outcomes in science learning for grade IV elementary school. Research conducted by Arifuddin (2018), the results show that there was a significant influence between the application of the inquiry learning model on students' mathematical problem solving abilities in fractional material in class IV MI Hidayatus Shibyan. Research conducted by Munandar (2019), show that inquiry learning through lesson study-based practicum was very effective in increasing mastery of respiratory system concepts and student activities during the learning process.

Based on the literature, this inquiry model is suitable applied in learning process to improve student learning outcomes. Inquiry-based learning, requires learners to think logically, analytically, and critically in searching, investigating, and finding answers towards problems contained in question (Abdullah, 2013). The effectiveness level of the inquiry learning model unseparated from the active role of students in learning process. The subject materials are not given directly, but needs students to participate actively in searching and finding the subject matter themselves, while the teacher acts as a facilitator and guide for students to learn. There are five stages in carrying out inquiry learning, namely: a) formulating problems that will be solved by students; b) determine a temporary answer or known as a hypothesis or problem; c) searching information, data, and facts which are needed to answer a hypothesis or problem; d) draw answers or generalizations; and e) draw conclusions (Trianto, 2009).

Based on the analysis of educational needs and students, the learning carried out has not used e-LKPD teaching materials that were prepared by the teacher themselves, but only LKPDs are available, even the available LKPDs are not necessarily compatible with the conditions in the field, which are definitely different between educational units. This causes the low learning outcomes of students. Therefore, innovation in learning is needed so that student learning outcomes can increase. Inquiry is one of the learning strategies that can be applied as a solution in improving student learning outcomes. Educators need e-LKPD which contains an inquiry learning model that is in accordance with the characteristics of students. Thus, it can be concluded that inquiry-based e-LKPD to improve student learning outcomes in elementary schools needs to be developed problem; c) seek information, data, and facts needed to answer hypotheses or problems; d) draw conclusions or generalizations; and e) draw conclusions (Trianto, 2009).

\section{Conclusion}

Based on the analysis of educational and students needs, the learning process had not used e-LKPD teaching materials that were prepared by teacher. They only used the available LKPDs which were not necessarily compatible with the actual conditions, since it was definitely different between educational units. This condition impact on the low learning outcomes of students. Thus, innovation in learning is needed to increase learning outcomes. Inquiry is one of the learning strategies that possibly to be applied as a solution in improving student learning outcomes. Educators need e-LKPD which contains an inquiry learning model which $\mathrm{s}$ in accordance with the characteristics of students. Thus, it can be concluded that the inquiry-based e-LKPD in elementary schools needs to be developed to improve student learning outcomes. 


\section{References}

Abdullah Sani, R. (2013). Inovasi pembelajaran. Jakarta: Bumi Aksara.

Arief, M. F. M. (2015). Pengembangan lembar kerja siswa (LKS) pada pembelajaran mekanika teknik dengan pendekatan kontekstual untuk siswa kelas X TGB SMKN 2 Surabaya. Jurnal Pendidikan Teknik Bangunan. 1(1), 148-152.

Arifuddin, Ahmad., Alfiani, Dwi Anita., \& Hidayati, Sri. (2018). Pengaruh model pembelajaran inkuiri terhadap kemampuan pemecahan masalah matematika siswa kelas IV Madrasah Ibtidaiyah. Al Ibtida Jurnal Pendidikan Guru MI. 5(2), 261.

Djamarah, S. B., \& Zain, A. (2002). Media pembelajaran. Jakarta: Rineka Cipta.

Hairida. (2016). The effectiveness using inquiry based natural science module with authentic assessment to improve the critical thinking and inquiry skills of junior high. Jurnal Pendidikan IPA Indonesia. 5(2), 209-215.

Kebudayaan, M. P. D., \& Indonesia, R. (2020). Surat Edaran Nomor 4 Tahun 2020 tentang Pelaksanaan Kebijakan Pendidikan dalam Masa Darurat Penyebaran Coronavirus Disease (COVID-19).

Khan, A., Egbue, O., Palkie, B., \& Madden, J. (2017). Active learning: Engaging students to maximize learning in an online course. The Electronic Journal of e-Learning. 15(2), 107-115.

Kristianto, Y. (2019). Penerapan model pembelajaran inkuiri untuk meningkatkan berpikir kritis dan hasil belajar siswa dalam pembelajaran IPA kelas IV SD. Jurnal Mitra Pendidikan. 3(11), 1428-1443.

Julian, Riana., \& Suparman. (2019). Analisis kebutuhan E-LKPD untuk menstimulasi kemampuan berpikir kritis dan pemecahan masalah. Science, Technology, Engineering, Economics, Education, and Mathematics. 1(1).

Maass, K. (2006). What are modelling competencies?. ZDM Mathematics Education. 38(2), $113-142$.

Miles, \& Huberman. (1990). Qualitative dan analysis a sourcebook of new methods. Alih bahasa oleh Munandir.

Mukhtar. (2013). Metode penelitian deskriptif kualitatif. Jakarta: GP Press Group.

Mulia, N. S., Azizah, A., \& Zaini, M. (2019). Penerapan pembelajaran berbasis inkuiri terhadap keterampilan berpikir kritis siswa MAN 3 Banjarmasin pada subkonsep bryophyta. Prosiding Seminar Nasional Lingkungan Lahan Basah Lembaga Penelitian dan Pengabdian kepada Masyarakat Universitas Lambung Mangkurat. 4(3), 625-629.

Murhamah, Shofiyatun, O., Nurlaelah, I., \& Setiawati, I. (2017). Penerapan model argument-driven inquiry (ADI) dalam meningkatkan kemampuan berargumentasi siswa pada konsep pencemaran lingkungan di kelas X SMA Negeri 1 Ciawigebang. Quagga: Jurnal Pendidikan dan Biologi. 9(02), 45.

Munandar, R. R., Sutjihati, S., \& Irpan, A. M. (2019). Efektivitas model pembelajaran inkuiri melalui praktikum berbasis lesson study terhadap penguasaan konsep sistem respirasi. Pedagonal/ Jurnal Ilmiah Pendidikan. 3(2), $10-17$.

Muzenda, A. (2013). Lecturer's competences and students' academic performances. Internasional Journal of Humanities and Social Science Invention. 3(1), 06-13.

Orton, A. (2004). Learning mathematics: Issues, theory and classroom practice. UK: A\&C Black.

Perignat, Elaine., \& Jennifer, Katz-Buonincontro. (2018). From STEM to STEAM: Using brain compatible strategies to integrate the arts . Arts Education Policy Review. 119(2), 107-110.

Putria, H., Maula, L. H. and Uswatun, D. A. (2020). Analisis Proses Pembelajaran dalam Jaringan (Daring) Masa Pandemi Covid-19 pada Guru Seklah Dasar. Jurnal Basicedu. 4(4), 861-872.

Putry, R. (2018). Gender equality: Internasional journal of child and gender studies. Journal of Child and Gender Studies. 4(1), 39-54.

Puspita, V. (2016). Developing student's reasoning skills by using modified investigation approach. International Seminar On Education (JISE). 1(1), 424-428.

Ramlawati, Liliasari Martoprawiro M. A., \& Wulan, A.R. (2014).The effect of electronic portfolio assessment model to increase of student's generic science skills in practical inorganic chemistry. J. Educ. L., 8 (3), 179-186.

Ramadhani, F. (2020). Penerapan model pembelajaran project based learning (PJBL) untuk meningkatkan hasil belajar ipa pada materi bioteknologi dan produksi pangan dalam pembelajaran daring. Jurnal Pelita Pendidikan. 8(4).

Sanjaya, Wina. (2006). Strategi pembelajaran. Jakarta: Kencana Prenada Media Group.

Sanjaya. (2013). Mendesain Model Pembelajaran Inovatif, Progresif. Konsep, Landasan, dan Implementasinya Pada Kurikulum Tingkat satuan Pendidikan (KTSP). Jakarta: Kencana Prenada Media Group.

Subakti, D., Marzal, J., \& Hsb, M. H. (2021). Pengembangan E-LKPD Berkarakteristik Budaya Jambi Menggunakan Model Discovery Learning Berbasis STEM Untuk Meningkatkan Kemampuan Berpikir Kreatif Matematis. Jurnal Cendekia : Jurnal Pendidikan Matematika. 5(2), 1249-1264. https://doi.org/10.31004/cendekia.v5i2.629

Suryosubroto, B. (2009). Proses belajar mengajar di sekolah. Jakarta: Rineka Cipta.

Trianto. (2009). Mendesain model pembelajaran inovatif progresif. Surabaya: Penerbit Kencana.

Trianto. (2013). Mendesaign model pembelajaran inovatif progresif. Jakarta: Kencana.

Turmudi. (2010). Matematika eksploratif dan investigatif. Jakarta: PT leuser Cita Pustaka.

Wenning, C.J., (2005). Levels of inquiry: Hierarchies of pedagogical practices and inquiry processes. Journal of Physics Teacher Education. 2(3), 3-12.

Yustini, E. P., Sadia, I. W., \& Setiawan, I. G. (2018). Analisis komparasi penggunaan model pembelajaran inkuiri bebas dan inkuiri terbimbing terhadap pemahaman konsep biologi ditinjau dari gaya kognitif siswa SMA. Jurnal Pendidikan dan Pembelajaan IPA Indonesia. Vol 8 (1).

Zahraa, Tatheer., Thamboob, Julian., Asada, Mohammad., \& Songa, Mengli. (2021). Experimental investigation on the effectiveness of lateral restrainers to the vertical steel in reinforced masonry walls under axial compression. Construction and Building Materials. 297, 123790. 